\title{
ACUTE CORONARY SYNDROME FOLLOWING LONG-TERM ERLOTINIB TREATMENT
}

\author{
Traian Constantin Panciu¹, Bianca Masgras ${ }^{1}$, Catrinel Ciuca ${ }^{1}$, Raluca Ciomag ${ }^{1,2}$, \\ Anca Mihăilescu'1,2, Adriana Gurghean ${ }^{1,2}$ \\ ${ }^{1}$ Clinical Hospital Colțea Bucharest, România \\ ${ }^{2}$ University of Medicine and Pharmacy Carol Davila Bucharest, Romania
}

\section{Rezumat}

Introducere. Tratamentul neoplaziilor a avansat grație terapiilor moleculare țintite. Erlotinib, inhibitor de tirozin-kinază, acționează prin blocarea receptorului factorilor de creștere epidermali (EGFR) este folosit în tratamentul cancerelor bronhopulmonare non-microcelulare local avansate sau metastatice rezistente la chimioterapie.

Erlotinibul este un medicament sigur și bine tolerat. Desi cele mai frecvente efecte adverse sunt cele cutanate sau gastrointestinale, cardiotoxicitatea sa este un subiect important în abordarea și urmărirea pacienților neoplazici.

Caz clinic. Pacient, 76 ani, fumător 40 pachete-ani sevrat de 20 ani, se prezintă în 2009 pentru transpirații nocturne, tuse seacă și scădere ponderală. Este diagnosticat cu neoplasm pulmonar în LSD (stadiul IV -T4N2M1), anatomopatologic adenocarcinom cu celule clare. Este radiotratat si polichimiotratat cu 6 serii de Gemcitabină și Cisplatin, cu răspuns parțial, urmat de tratament cu Erlotinib. Evoluția a fost favorabila, cu regresie a dimensiunilor tumorale.

În decembrie 2017, afirmă episoade recurente de angină atipică cu durata de aproximativ 2 săptămâni. Examenul electrocardiografic evidențiaza supradenivelare segment ST, unde T hipervoltate și unde $Q$ prezente în derivațiile inferioare, asociind creșterea enzimelor de necroză miocardică. Ecocardiografia pune in evidenta insuficiența mitrală ușoară și hipokinezie inferioară cu FE 45\%. Pacientul are o evoluție favorabila sub tratament pe parcursul internarii, fără recurența durerii. La distanță se efectuează coronarografie cu evidențierea leziunilor aterosclerotice bivasculare și montarea de stenturi farmacodinamic active.

Discuții. Inhibitorii de tirozin-kinază ar putea fi cauza unor evenimente coronariene acute atât prin afectarea miocardiocitelor consecutivă inhibării EGFR, dar și prin cresterea instabilități plăcilor de aterom și prin lungirea segmentului QT.

In concluzie, ar putea fi recomandată o evaluare cardiologică sistematizată a pacienților aflați în tratament cu Erlotinib pe durata întregii terapii.

Cuvinte cheie: Erlotinib, inhibitor de tirozin-kinază, cancer bronhopulmonar nonmicrocelular, sindrom coronarian acut. 


\title{
INTERNAL
}

\section{Clinical cases}

\begin{abstract}
Introduction. The treatment of neoplasia has advanced due to targeted molecular therapies. Erlotinib, a tyrosine kinase inhibitor that acts by blocking epidermal growth factor receptor (EGFR), is used to treat advanced or metastatic chemotherapy-resistant non-small cell lung cancers (NSCLC).

Erlotinib is a safe and well tolerated medication. Although the most common adverse effects are cutaneous or gastrointestinal, its cardiotoxicity is an important topic in the treatment and follow-up of neoplastic patients.
\end{abstract}

Clinical case. A 76-year-old male patient with 40 Pack Year history of smoking that has quitted 20 years ago, was admitted in 2009 for night sweats, dry cough and weight loss. He is diagnosed with lung cancer in the right upper lobe ( T4N2M1), with the histopathological diagnosis of clear cell adenocarcinoma. The patient performs radiotherapy and chemotherapy with 6 series of Gemcitabine and Cisplatin with partial response, followed by Erlotinib treatment with favorable progression with regression of tumor size.

In December 2017, he presents recurrent episodes of atypical angina lasting about 2 weeks. The electrocardiographic examination reveals ST segment elevation, with tall T waves and $Q$ waves are present in the lower branches, associated with the increase of myocardial necrosis enzymes. Echocardiography highlights inferior hypokinesia with left ventricle ejection rate estimated at $45 \%$. The patient has a favorable evolution during admission without recurrence of pain. Coronary angiography is performed at distance with evidence of vascular atherosclerotic lesions and the installation of active pharmacodynamic stents.

Discussions. Tyrosine kinase inhibitors may be the cause of acute coronary events both by affecting myocardiocytes following EGFR inhibition, but also by increasing atheromatic plaque instability and by prolonging the QT segment.

In conclusion a systemic cardiologic assessment of Erlotinib-treated patients may be recommended throughout the course of therapy.

Keywords: Erlotinib, tyrosine kinase inhibitor, non-small cell lung cancer, acute coronary syndrome. 
The treatment of neoplastic patiens has received numerous power-ups over the past years following the development of targeted molecular therapies. Erlotinib, a tyrosine kinase inhibitor that acts by blocking epidermal growth factor receptor (EGFR), a medication that has showed an improved survival rate and good tolerance, is used to treat advanced or metastatic chemotherapyresistant non-small cell lung cancers (NSCLC) as a second line agent and for patients with sensitizing EGFR mutations it is used as a first line agent.

Altough this kind of molecules were considered relatively safe,considering that they are going to affect only tumors, not normal tissues, in the years following the introduction of targeted therapies into the oncological treatment, clinical trials started to show different adverse effects of the tyrosine kinase inhibitors, one of them mild ( cutaneous or gastrointestinal), some of them major, among which cardiotoxicity ${ }^{(1)}$.

Related to Erlotinib, not so many cases of cardiovascular events were reported, and causality relationship may still be questionable, but the additive effect is one to be taken into account. Under this circumstances, we present one case in which erlotinib may have been another brick in the crumbling wall.

\section{Case presentation}

A 76-year-old male patient with 40 Pack-Year history of smoking that has quitted 20 years ago, without a history of cardiovascular disease, no history of tuberculosis, diabetes mellitus, dyslipidaemia, hypertension or neoplasia. He worked as a truck driver and he was curently living a the rural area. He was admitted in 2009 for night sweats, dry cough and weight loss of about 10kilograms in 6 months. A pulmonary radiography is performed revealing an opacity of about 6-7 $\mathrm{cm}$, in the ventral segment of the right upper lobe (RUL).

The diagnostic algorithm followed and a CT scan is performed showing a tumor that infiltrates and compresses the right branch of the pulmonary arteries and the upper right lobar bronchus. The tumor confluences with tracheal and hilar adenopathy blocks formating a mass of about $8 \mathrm{~cm}$ in diametre and comes in contact with the right laterothoracic wall. Much more, osteocondensing lesions (C7 + left iliac area) are shown. Bronchoscopy is performed evidentiating a necrotic tumor obstructing the ventral segmentary of the right upper bronchia. The biopsy reveals bronchial mucosa with clear cell adenocarcinoma infiltration.

Therefore, he is diagnosed with lung cancer in the right upper lobe (T4N2M1), with the histopathological diagnosis of clear cell adenocarcinoma. Taking in consideration the inoperability status of the patient, he is referred to oncology department where 6 cycles of chemotherapy with Gemcitabine and Cisplatin were performed with partial response. Forwards, radiotherapy is fullfield with mediastinal irradiation.

At follow-up, CT scan shows a reduction in dimensions of the pulmonary tumor, but new osteocondensing lesions appear. Therefore, treatment enters phase 11 , erlotinib administration being started with a $150 \mathrm{mg}$ each day regime. In a promising way, several CT scans performed afterwards showed a decrease of the tumoral mass and of the adenopathies without the occurrence of new osteocondensing lesions. Fortunately, no major side effects occurred during the past few years, cutaneous rash and diarrhea were reported relatively frequently, but with a good tolerance. 


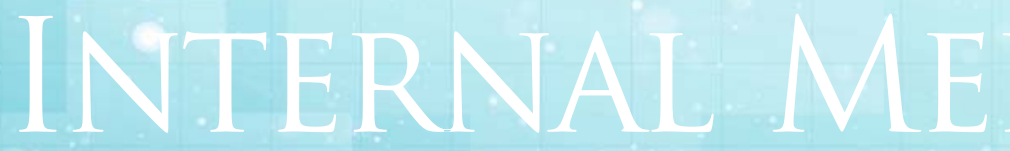

\section{Clinical cases}

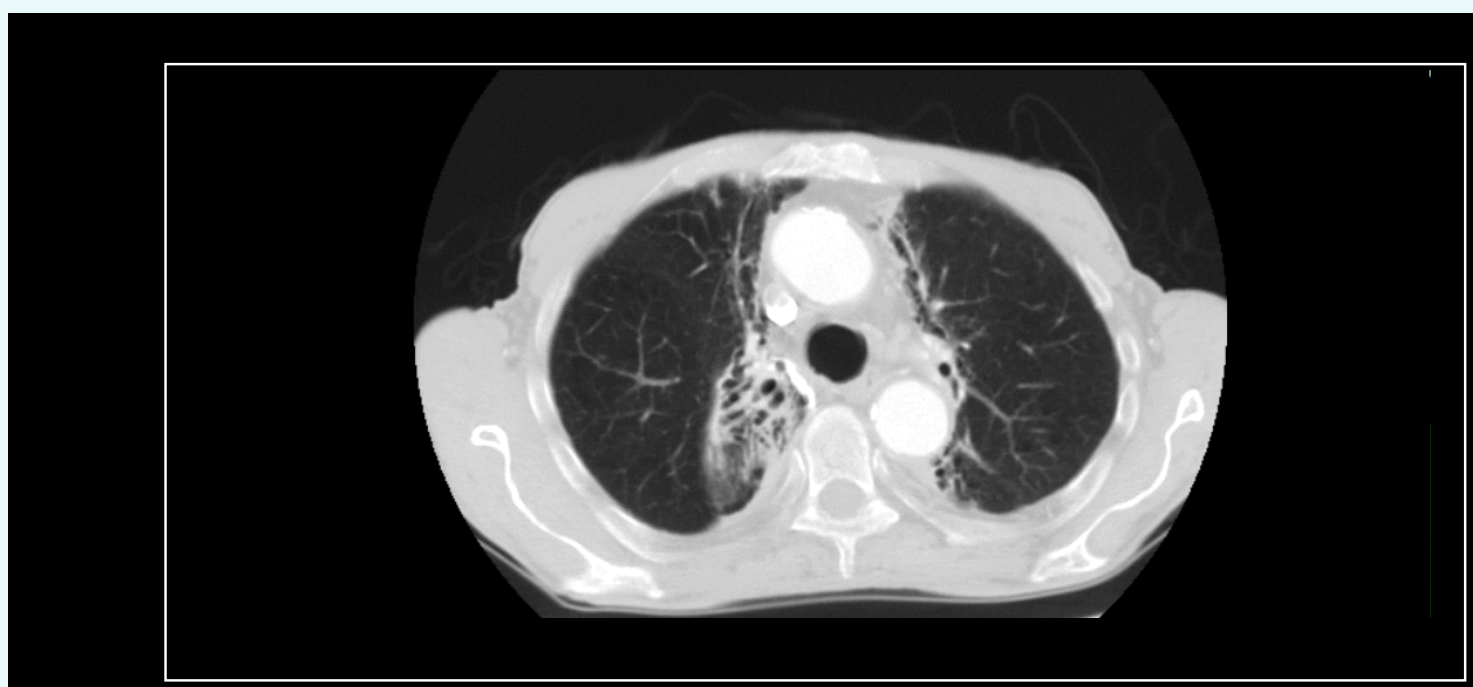

Figure 1. CT realised at 1 year follow up showing dramatic reduction of tumoral size in RUL, together with post radiotherapy fibrotic lessions

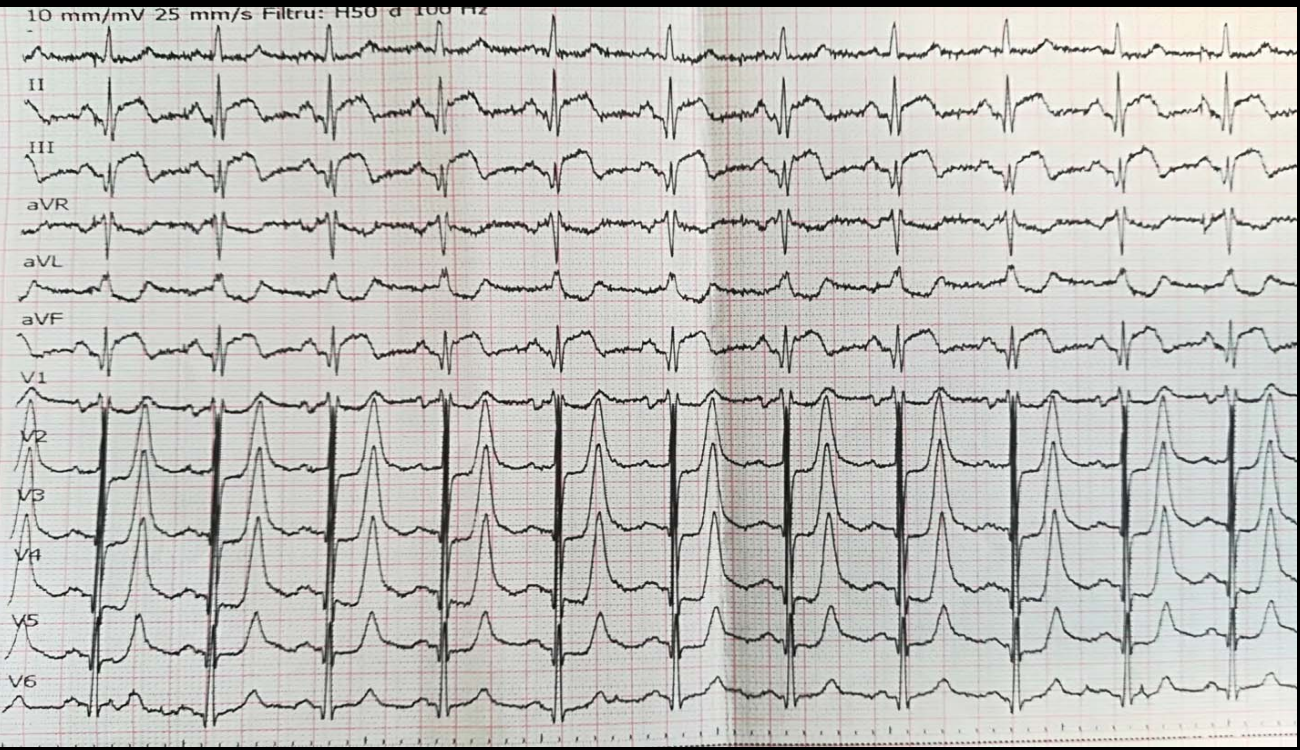

Figure 2. ECG reveals ST segment elevation, with tall $T$ waves and $Q$ waves that are present in the lower branches, with a normal QT segment 
In December 2017, at a routine follow-up visit, patient reports recurrent episodes of sharp pain in the right subclavicular area, appear and disappear spontaneously. This episodes started 2 weeks ago, without any asociating symptoms and the patient interprets them as being more or less benign. Clinical exam shows a relatively good general condition, BMI 21, dehydrated skin, blood presure of $150 / 80 \mathrm{mmHg}$ (with a history in the past few years of higher values at various measurements), pulse rate of $80 \mathrm{bpm}$, saturation of oxygen at $96 \%$ in the room air, rhythmic cardiac noise, no pulmonary rales, no ankle edema. The electrocardiographic examination reveals ST segment elevation, with tall $\mathrm{T}$ waves and $\mathrm{Q}$ waves that are present in the lower branches, with a normal QT segment.

This modification were associated with increase of myocardial necrosis enzymes, with a high level of Troponine, CK and CK-MB. Echocardiography shows us normal dimensions of cardiac chambers, with mild mitral regurgitation, aortic valve calcification and inferior hypokinesia with left ventricule ejection rate estimated at $45 \%$. The patient was considered to have experienced a subacute myocardial infarction and thus erlotinib treatment was discontinued immediately.

Consequently, patient could not be transferred in to a specialised centre for coronary acute events so therefore, conservatory treatment is initiated with administration of high dose statines, dual antiplachetar therapy with aspirine and clopidogrel, low weight molecular heparine, beta blockers, ACE inhibitors and slow release nitrates with a favorable evolution during admission without recurrence of pain. After the release from our department, the oncologist decided to restart the administration of erlotinib at the same dose as before. Coronarography is performed 2 months distance from the event, evidentiating bivascular atherosclerotic lesions, with $90 \%$ stenosis of circumflex artery and 100\% stenosis of right coronary artery followed by the placement of 3 active pharmacodynamic stents. At the time of publication, the patient was stable from cardiovascular point of view, and with no progression of the tumor size under Erlotinib treatment.

\section{Discussions}

Associations between erlotinib treatment and an acute coronary event in our patient may sound a little bit exaggerated, considering his risk factors and pathologies that increase cardiovascular risk. Lung cancer, history of smoking, cycles of mediastinal radiotherapy, hypertension, are each one of them major culprits of this acute episode. But why not considering that erlotinib, a TKI, may also be added to this long tally of risk factors, which were combined in an unfortunate way in our patient? Keeping in mind that several pathological mechanism may be eased up by Erlotinib treatment such as atheroma plaque instability, direct myocardial toxicity, effects on $K$ channel that may precipitate arrhythmias, or even the global toxicity this drug may induce in the patient homeostasis, we add our strong opinion that Erlotinib may have been another strong factor in the etiology of this episode ${ }^{(2)}$.

Although several studies, especially in vitro ones, affirmed that TKI may be cardiotoxic, they also have indicated that Erlotinib may have close to zero cardiotoxicity, in vivo we are in the situation were we have to admit such adverse effects. Considering that TKI adverse effects may range from 


\section{INTERNAL}

\section{Clinical cases}

asymptomatic subclinical events such as ECG modifications and left ventricular ejection fraction alteration to life threatening episodes, especially congestive heart failure and acute coronary syndromes it was not hard to convince us to dig further into TKI toxicity. After finding out a few case reports ${ }^{(3,4)}$ from different type of patients which were considered to be potentially affected by erlotinib, we postulate that every each and one of this kind of events must be reported and seriously evaluated.

We consider that cardiac toxicity caused by erlotinib treatment requires serious attention from the physicians, even though their adverse effects are less pronounced than other TKI. Caution and attentions must be paid when administering TKI, such as erlotinib, to patients with advanced neoplasia, particularly elderly patients or those with a history of coronary heart disease $^{(5)}$. We have to emphasize the fact that a comprehensive assessment of the patients should be performed before starting the treatment, and also that ECG, echocardiography and myocardial enzymes testing must be performed at on a scheduled basis so that serious adverse reactions may be identified early in their progression and managed quickly.

\section{References:}

1. Orphanos GS1, Ioannidis GN, Ardavanis AG. Cardiotoxicity induced by tyrosine kinase inhibitors. Acta Oncol. 2009; 48(7):964-70.

2. Ming Hui Chen, Risto Kerkelä, Thomas Force. Mechanisms of Cardiac Dysfunction Associated With Tyrosine Kinase Inhibitor Cancer Therapeutics. Circulation. 2008;118:84-95

3. SHANSHAN DING, FEI LONG, and SHUJUAN JIANG. Acute myocardial infarction following erlotinib treatment for NSCLC: A case report. Oncol Lett. 2016 Jun; 11(6): 4240-4244

4. Tulay Kus, Gokmen Aktas, Alper Sevinc, Mehmet Emin Kalender, and Celaletdin Camci. Could erlotinib treatment lead to acute cardiovascular events in patients with lung adenocarcinoma after chemotherapy failure?. Onco Targets Ther. 2015; 8: 1341-1343.

5. Merimsky O1, Cheng CK, Au JS, von Pawel J, Reck M. Efficacy and safety of first-line erlotinib in elderly patients with advanced non-small cell lung cancer. Oncol Rep. 2012 Aug;28(2):721-7. 